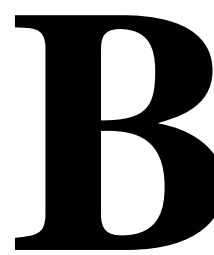

\title{
USINESS MODELS AND COMPETITIVE ADVANTAGE: A DYNAMIC APPROACH
}

\author{
${ }^{1}$ Soraya Cardoso Pongelupe Lopes \\ ${ }^{2}$ Humberto Elias Garcia Lopes \\ ${ }^{3}$ Karina Garcia Coleta \\ ${ }^{4}$ Vivian Cândido Rodrigues
}

\begin{abstract}
Objective: Demonstrate how the Canvas business model can become dynamic from a conceptual perspective.
\end{abstract}

Methodology/approach: This study is qualitative, descriptive and exploratory, with a theoretical approach, based on the foremost theorists.

Originality /Relevance: This study presupposes the importance of strengthening the business model literature on the competitive dynamic perspective. It defines the assumptions of a DMB and differentiates it from a static model. That enables the evaluation of the factors that cause a BMC to become static and thus not equipped to allow a business logic that creates value and generates a competitive advantage.

Main results: At the end of the present essay, it is possible to understand, from a theoretical perspective, how the DBM contributes to value creation and the generation of sustainable advantage in high-change environments.

Theoretical/methodological contributions: The present study has identified three conceptual assumptions that constitute the DBM. First, there is the design of the business models - interdependence and connection between their constitutive elements. Second, the business models linked to dynamic capabilities. Finally, the search for the capture of value and generation of sustainable competitive advantages by the companies. By those assumptions, it was possible to introduce a conceptual model for DBM and BMC evaluation from the perspective of a dynamic model.

Keywords: Business Models, Competitive Advantage, Canvas, Dynamic Approach.

\section{Cite it like this:}

Lopes, S., Lopes, H., Coleta, K., \& Rodrigues, V. (2019). Business Models and Competitive Advantage: A Dynamic Approach. Revista Ibero-Americana De Estratégia, 18(1). 90-105. https://doi.org/10.5585/ijsm.v18i1.2698

1 Pontifícia Universidade Católica de Minas Gerais - PUC Minas, Minas Gerais, Brasil. Email: sorayacardoso@pucminas.br Orcid Id: https://orcid.org/0000-0002-0329-7300

2 Pontifícia Universidade Católica de Minas Gerais - PUC Minas, Minas Gerais, Brasil. Email: heglopes@pucminas.br Orcid Id: https://orcid.org/0000-0002-6207-2726

3 Pontifícia Universidade Católica de Minas Gerais - PUC Minas, Minas Gerais, Brasil. Email: karinacoleta@gmail.com Orcid Id: https://orcid.org/0000-0002-5203-5673

4 Pontifícia Universidade Católica de Minas Gerais - PUC Minas, Minas Gerais, Brasil. Email: viviancandido@yahoo.com.br Orcid Id: https://orcid.org/0000-0001-6471-7471 


\section{MODELOS DE NEGÓCIO E VANTAGEM COMPETITIVA: UMA ABORDAGEM DINÂMICA}

\section{Resumo}

Objetivo: Demonstrar como o modelo de negócio Canvas pode se tornar dinâmico a partir de uma perspectiva conceitual.

Metodologia / abordagem: Este estudo é de natureza qualitativa, descritiva e exploratória, com abordagem teórica, baseada nos principais teóricos.

Originalidade / Relevância: Este estudo pressupõe o fortalecimento da literatura de modelo de negócio na perspectiva da competitividade dinâmica. Ele define modelo de negócio dinâmico e o diferencia de um modelo estático. Isso permite avaliar os fatores que fazem com que um modelo de negócio se torne estático e, portanto, não esteja preparado para uma lógica de negócios que crie valor e gere vantagem competitiva.

Principais resultados: No final do ensaio, foi possível entender, a partir de uma perspectiva teórica, que o Modelo de Negócio Dinâmico contribui para a criação de valor e a geração de vantagem sustentável em ambientes de alta mudança.

Contribuições teórico-metodológicas: Este estudo identificou três pressupostos conceituais que constituem o modelo de negócio dinâmico. Primeiro, o desenho dos modelos de negócios - interdependência e conexão entre seus elementos constitutivos. Em segundo lugar, os modelos de negócios ligados a capacidades dinâmicas. E por fim, a busca pela captura de valor e geração de vantagens competitivas sustentáveis pelas empresas. A partir dessas conclusões, foi possível avaliar o modelo de negócio Canvas na perspectiva de um modelo dinâmico.

Palavras-chave: Modelos de negócio, Vantagem Competitiva, Canvas, Abordagem Dinâmica.

\section{MODELOS DE NEGOCIO Y VENTAJA COMPETITIVA: UM ENFOQUE DINÁMICO}

\section{Resumen}

Objetivo: Demostrar cómo el modelo de negocio Canvas puede convertirse en dinámico desde una perspectiva conceptual.

Metodología / enfoque: El presente estudio es de naturaleza cualitativa, descriptiva y exploratoria, con enfoque teórico, basada en los principales teóricos.

Originalidad / Relevancia: Este estudio presupone el fortalecimiento de la literatura de modelo de negocio en la perspectiva de la competitividad dinámica. Se define el modelo de negocio dinámico y lo diferencia de un modelo estático. Esto permite evaluar los factores que hacen que un modelo de negocio se vuelva estático y, por lo tanto, no esté preparado para una lógica de negocios que crea valor y genere una ventaja competitiva.

Principales resultados: Al final del ensayo, fue posible entender, desde una perspectiva teórica, que el Modelo de Negocio Dinámico contribuye a la creación de valor y la generación de ventaja sostenible en ambientes de alto cambio.

Contribuciones teórico-metodológicas: El presente estudio identificó tres supuestos conceptuales que constituyen el modelo de negocio dinámico. Primero, el diseño de los modelos de negocios - interdependencia y conexión entre sus elementos constitutivos. En segundo lugar, los modelos de negocio vinculados a las capacidades dinámicas. Y por último, la búsqueda por la captura de valor y la generación de ventajas competitivas sostenibles por las empresas. A partir de estas conclusiones, fue posible evaluar el modelo de negocio Canvas en la perspectiva de un modelo dinámico.

Palabras clave: Modelos de Negocio, Ventaja Competitiva, Canvas, Enfoque Dinámico. 


\section{INTRODUCTION}

Information and technology have a significant impact on the business environment. Both variables shape the competitive scenario for business firms and organizations moving them towards high ground competition. By its turn, that kind of competition demands agents prepared to face shorter product lifecycles and to manage a complex network of partners, shareholders, and customers. When firms and organization accomplish both demands, they can capture more value and even experience a sustainable competitive advantage.

However, in those high ground competitive markets the term "competitive advantage" is sometimes unclear. That is a result of not taking into account the two underlying approaches of that term. The first one is the temporary approach that emphasizes markets be all dynamic in the short time (D'Aveni et al., 2010). It means that firms and organization need to continually update information on products and network management to meet the unstable and movable market demands.

The second one is the sustainable approach. It claims that, after serving market demands, firms and organizations need to develop and implement actions to allow them to maintain a valuable competitive position. The implication of that is they have to focus on how to capture long-term value continuously through their business uniqueness, the nonreplicability of their business models, and their ability of effectively substitute resources (Adner and Zemsky, 2006; Teece, 2014).

The two competitive advantage approaches temporary and sustainable - address significant pitfalls for business models. The first one is that both the literature and the managerial practice embrace an absolute emphasis on the ability of business models in dramatically shape firms' and organizations' structure and processes towards unique features that are supposed to maintain their competitive advantage over competitors.

The second one is a result of the first one: academics and practitioners are navigating in the shadows of uncertainty when they try to understand how business models could be useful in the shorttime conditions of the high ground competitive markets. That means the usual sustainable approach of dealing with long-term, static business models can be challenging to deal with the unstable conditions of markets in which nontheoretical firms and organizations operate. That said, it is mandatory to identify and understand how a short-term and dynamic view of business models could suitably manage the demands of those who need to make critical decisions concerning their logic of capturing value on the short-term.

The way of accomplishing that is to address the so-called dynamic business model (DBM), that can be the basis for firms and organizations creating and capturing value (Amit and Zott, 2014).

The DBM reinforces competitive adaptation in the short-term since it can rethink, adapt, transform or replace the traditional static business models into competitive environments (Amit and Zott, 2014; Osterwalder and Pigneur, 2010, 2002; Teece, 2018). Hence, the DBM can allow firms to capture value and generate a sustainable, competitive advantage.

Academic and practitioners usually acknowledge the business model canvas framework (BMC) as an example of a dynamic business model. For that reason, the BMC became remarkably popular in the business environment, emerging as an alternative for highly competitive markets. Osterwalder (2004) firstly enhanced that view by broadly defining the $\mathrm{BMC}$ as the logic of how a company makes money.

In that view, the BMC is a tool for accouching dynamic management, being able to rebuild itself and modify the business plan of firms and organizations.

Consequently, it would no longer operate as a subsidiary visual and static map of the business. Despite that, the nature of the BMC is mostly static, registering a seeming incoherence between its purpose and execution (Osterwalder, 1994).

The BMC is a suitable tool for helping academics and practitioners to understand how unstable business environments work in the real world. At the same time, the literature indicates the BMC developed as an initially static framework. Because of that, the question is to know if the BMC is a useful tool for dealing with unstable and dynamic markets.

This paper faces that question going further in the literature on dynamic business models (DBM). It identified three conceptual assumptions upon DBM. First, there is the design of the business model interdependence and connection between their constitutive elements. Second, the business models 
linked to dynamic capabilities. Thirdly, the search for the capture of value and generation of sustainable competitive advantages by firms. Through those assumptions, this paper proposes a new theoretical model that connects the dynamic viewpoint to the BMC.

This paper also regards the need for strengthening the business model literature on the competitive dynamics perspective. It compares the assumptions of DMB and static models. Because of that, it evaluates the portions that cause a BMC to become static and not outfitted to adopt a business logic that creates value and generates a competitive advantage.

Furthermore, this paper also explains business models as the result of the strategic representation of value creation and capture, which contributes to the competitive advantage of the business(CasadesusMasanell and Ricart, 2010; Pitelis, 2009).

\section{The Definition And Assumptions of the Dynamic Business Models}

The business model concept arose in the literature with Drucker in the 1960s (Osterwalder, 2004). However, that would only build in relevance during the 1990s. Digital markets began to grow with dotcom firms, which used the business model concept to identify the synthesis of a business idea.

Currently, there is no consensus in the literature on the business model concept that brings an end to the matter (Shafer et al., 2005; Teece, 2010; Wirtz et al., 2016).

Initially, the challenge and the disagreement encompassing that concept influenced its understanding. That happened because it joins the simplified representation of the real and physical world (Osterwalder et al., 2005), also with the action of buying and selling, and even the processes of business (Gordijn et al., 2000). Contemporary debates lead to approaches that treat the business models as representations of traditional enterprises.

However, there is a continuous change that plays an innovative role in the business models for value capture (Zott and Amit, 2013). There are various updates of the definitions applied to the business models, usually linked to the viewpoint of causing competitive advantage through value creation and capture (Afuah and Tucci, 2003; Amit and Zott, 2001; Casadesus-Masanell and Ricart, 2011; Demil and Lecocq, 2010; Osterwalder, 2004; Osterwalder and Pigneur, 2010; Shafer et al., 2005; Zott and Amit, 2007).

From the viewpoint of value capture (Amit and Zott, 2001; Zott et al., 2010) regard that the business models depict the contents of transaction, structure, and governance to create value by exploring business opportunities. Moreover, they further state that the business model is the business logic directly associated with the generation of revenue for all stakeholders (Zott et al., 2010).

The definition is in the business logic, in its operating mode, in how it captures value for the relevant parts and does the interface between business strategy and tactics (Casadesus-Masanell and Ricart, 2009). The business models also link activities of doing business, such as design, purchase, and manufacture (Magretta, 2002). They integrate core activities, describing how companies work.

Demil and Lecocq (2010) bring the business model definition closer to the activities and resources used to guarantee the sustainability and dynamic growth of the model.

From the viewpoint of value capture, business models demand the connection between multiple competencies with partners, focusing on the market sector (Zott and Amit, 2013). The DBM transforms itself over time, following the evolutions in the market, technology and legal structures (Teece, 2010). This fluidity is considered a sustainable advantage factor as it allows for value creation in a continuous flow of adaptation and renewal (Achtenhagen et al., 2013).

Studies on business models have not made progress on how companies should change, adapt or innovate to create value and maintain their advantage (Achtenhagen et al., 2013).

Despite that, scholars addressing the issue have identified theoretical axes and assumptions for the constitution of the DBM vis-à-vis the static model. Hence, there are three essential assumptions from the theory of constituting the dynamic model (Fig.1). 
Soraya Cardoso Pongelupe Lopes, Humberto Elias Garcia Lopes, Karina Garcia Coleta \& Vivian Cândido Rodrigues

\begin{tabular}{|c|c|c|c|}
\hline $\begin{array}{l}\text { Theoretical } \\
\text { Assumptions }\end{array}$ & Static Model & Dynamic Model & References \\
\hline $\begin{array}{l}\text { business model } \\
\text { design - } \\
\text { interdependence } \\
\text { and connection } \\
\text { between } \\
\text { constitutive } \\
\text { elements }\end{array}$ & $\begin{array}{l}\text { Its function is to describe } \\
\text { the business model of the } \\
\text { company. } \\
\text { The design is not } \\
\text { concerned with the } \\
\text { fluidity and } \\
\text { correspondence amongst } \\
\text { model components. }\end{array}$ & $\begin{array}{l}\text { Its function is to describe, } \\
\text { manage and innovate the } \\
\text { business models of the } \\
\text { companies. } \\
\text { Requires a design that promotes } \\
\text { interaction between and } \\
\text { integration of components. } \\
\text { Operates with quantitative and } \\
\text { qualitative metrics and } \\
\text { indicators that are capable of } \\
\text { creating connection and } \\
\text { assessment of the model. }\end{array}$ & $\begin{array}{l}\text { (Achtenhagen et al., } \\
\text { 2013; Afuah and Tucci, } \\
\text { 2003; Amit and Zott, } \\
\text { 2015; Demil et al., 2015; } \\
\text { Demil and Lecocq, 2010; } \\
\text { Plé et al., 2010a; Wirtz et } \\
\text { al., 2016) }\end{array}$ \\
\hline $\begin{array}{lr}\text { business } & \text { model } \\
\text { linked to a } \\
\text { strategic } \\
\text { conception } \\
\text { dynamic } \\
\text { capacities }\end{array}$ & $\begin{array}{l}\text { It does not necessarily } \\
\text { correspond to a business } \\
\text { strategy. } \\
\text { It might not consider } \\
\text { mapping and learning } \\
\text { mechanisms about } \\
\text { information that is } \\
\text { external or internal to the } \\
\text { company. }\end{array}$ & $\begin{array}{l}\text { The strategy is concerned with } \\
\text { the structuration, construction, } \\
\text { and alteration of the dynamic } \\
\text { and managerial capacities. It } \\
\text { makes use of tools and analyses. } \\
\text { It develops the capacities of } \\
\text { sensing threats and } \\
\text { opportunities, learning and } \\
\text { transforming the business. }\end{array}$ & $\begin{array}{l}\text { (Achtenhagen et al., } \\
\text { 2013; Amit and Zott, } \\
\text { 2014; DaSilva and } \\
\text { Trkman, 2014; Demil et } \\
\text { al., 2015; Teece, 2014, } \\
\text { 2010) }\end{array}$ \\
\hline $\begin{array}{l}\text { Search for value } \\
\text { creation and the } \\
\text { generation of } \\
\text { sustainable } \\
\text { competitive } \\
\text { advantage }\end{array}$ & $\begin{array}{l}\text { It might capture or even } \\
\text { create value, but has no } \\
\text { intention of prolonging } \\
\text { this advantage for a } \\
\text { protracted period. }\end{array}$ & $\begin{array}{l}\text { Extrapolates value capture in } \\
\text { order to create value and } \\
\text { consequently to generate } \\
\text { sustainable } \\
\text { advantage. }\end{array}$ & $\begin{array}{l}\text { (Achtenhagen et al., } \\
\text { 2013; Casadesus- } \\
\text { Masanell and Ricart, } \\
\text { 2010; Demil et al., 2015; } \\
\text { Massa et al., 2017; } \\
\text { Teece, 2018, 2010; Wirtz } \\
\text { et al., 2016; Zott and } \\
\text { Amit, 2013) }\end{array}$ \\
\hline
\end{tabular}

Figure1: Conceptual differentiation between static and dynamic business models. Source: Elaborated by the authors.

Firstly, the design of the business model interdependence, and linkage between constitutive elements. Secondly, the business model linked to a strategic conception of dynamic capacities. Thirdly, the search for the creation of value and generation of sustainable competitive advantage. Although these theoretical axes disperse throughout the BM literature, explicitly identifying the assumptions of each of the constructs will enable the conceptualization and the differentiation between a static and a dynamic model.

The fundamental difference between the two models is the company's intention of designing a business, meaning that the analysis becomes static and restrained to a specific period (Fritscher and Pigneur, 2015). From a different standpoint, the firm uses its business model to develop, change and promote value capture for lasting periods of time (Achtenhagen et al., 2013). Figure 1 shows that, for every theoretical assumption, there is a broadening of principles and domains that structure the constructs of a DBM.

\section{The Interdependence and Connection Between Components of the Business Model Design}

The interaction between the operational structure and the components that constitute the business model presented by Demil and Lecocq (2010) is also called the business model design. Further endorsing this conception, Afuah and Tucci (2003) describe the business model as a system of activities constituted by components and dynamic connections. Amit and Zott (2015) also include the interdependence between the components.

Amit and Zott (2015) emphasize that business models be static to some extent, as they do not establish connections and interdependence between their components. Furthermore, business models do not work as recursive systems between conception and implementation (Demil et al., 2015). 
Moreover, the analysis of business models components is heterogeneous. The broadest consensus that has been achieved by various authors refers to market variables and resources, some of which linked to the business strategy. An example is the customer element, which is interrelated with the value creation element (Wirtz et al.,2016).

The process of grouping, as well as the links, connections, and the dynamics of the components or activities of a business model, are fundamental to the scope of creation and capture of value (Afuah and Tucci, 2003; Amit and Zott, 2015). That process interconnects and co-ordinates the interdependencies of activities as an outcome of the business architecture of the metamodel (Amit and Zott, 2015). Achtenhagen et al. (2013) go even further, as they include interconnected actions and resources both internal and external to the business model, facilitating the capture of sustainable value. They also reaffirm the need to adapt and renew the models by taking the inner connection of their elements into consideration.

As a result, the DBM no longer merely describes but undertakes the logic of creating, implementing and recreating businesses (Teece, 2010;2018) Furthermore, it modifies the static conception of the elements into a systemic view of connection and interdependence between its components. It also adopts additional actions and monitoring parameters (metrics) for the performance of its activities (Amit and Zott, 2015).

\section{Business Models Under a Dynamic Capability Approach}

The premise of the dynamic model is related to strategy, and different studies point out the discrepancies between the concept of strategy and the concept of business models. Chesbrough and Rosenbloom (2002), as well as (Zott and Amit, 2013, 2010), identify similarities between strategy and business models based on the different concepts proposed for DBM, such as value capture and dynamic capacities. Casadesus-Masanell and Ricart (2011) also consider the business models to be a representation of the strategy that firms adopt.

DaSilva and Trikman (2014) considered a different viewpoint, affirming that strategy involves the structuration, construction, and alteration of the dynamic capabilities that respond to present and future demands through the business models.

Mostly, there are three research lines in the business literature. One of them is rooted in the
Industrial Organisation (IO), which is concerned with the structure, choice of position and economic value of industries. This theory aims at a rational outside-in approach (Ghemawat, 2002). Its weakness stands on the rigid structure of assessing the environmental conditions, with no evaluation of complementarities, support institutions, conservative possibilities, as well as the static nature of the provision of feedback concerning internal development (Teece, 2007).

Also, from an outside-in perspective, the understanding of the focal firm has been developed and expanded. It holds the conception of a business ecosystem that transcends the limits of the focal firm, adapting itself to a systemic perspective that creates interdependencies and complementarities of the firm as it captures value (Zott and Amit, 2013).

The second theory is the resource-based theory (Barney, 1991). It focuses on the development and use of existing resources within the firm to capture value and reduce imitation. Contrary to the positioning theory, resource-based theory adopts an inside-out point of view.

The resource-based business model has been under negative scrutiny regarding its inability to account for what makes resources valuable, rare, inimitable and irreplaceable (Priem, 2007). Moreover, this model is referred to as static as it does not promote the continuous acquisition of competencies. Hence, it is necessary to adopt an additional construction process, such as Nonaka's spiral of knowledge (Teece, 2014).

The third theory is the dynamic capacities approach, which assumes complex business ecosystems and lively transformations, outlined by uncertainties and conflicts.

That theory is linked to the concept of strategic entrepreneurship and focuses on the capacities of companies to integrate, develop and reconfigure internal and external capabilities to innovate and capture value (Nelson and Winter, 1982; Teece, 2014; Teece et al., 1997).

Another component that strengthens the dynamicity of the business models is the entrepreneurial strategic vision of business making. It renews the business models approaches by describing threats as well as taking advantage of and transforming the opportunities constructed by the dynamic capabilities (Teece, 2007;2018). 
The present study will provide a detailed section on the assumptions and characteristics incorporated by the business models linked to the theory of dynamic capabilities.

\section{The Dynamic Business Model as a Tool to Create and Capture Value}

The terms value creation and value capture developed from strategy theory. However, that subject matter has experienced conceptual metamorphoses that have converged on the concept of competitive advantage.

The conception of value in positioning theories is understood as economic value - in other words, profitability or the return on investment - given by the levels of satisfaction of perceived benefits minus the relative position of the costs. In doing so, companies that sustain themselves at the maximum value of the productivity frontier obtain competitive advantage (Porter and Millar, 1985). Although it advances on the conceptualization of an extended competition for value, this approach is rooted in the perspective of costs of the Industrial Organisation, heading to the attractiveness and competitive position of the companies in the market (Ghemawat, 2002).

As to the resource-based theory, it differentiates itself from the positioning perspective. The starting point for firm performance is the bundle, as well as the singular combination of resources and competencies (Barney, 1991). That theory assumes that firms achieve and maintain the competitive advantage when those resources are valuable, rare, hard to imitate, and non-substitutable (Barney, 1991).

However, on its own, the resource scarcity in the market might lead to ambiguity about the sustainable competitive advantage. Within the theory of dynamic capabilities, the opportunities are the goal of excelling competitive advantage (Teece, 2007) as well as a development of the capability of the creation of scarce resources, the identification of opportunities and the strategic implementation of valuable assets for the customer. Technological innovation is one of the mechanisms for capturing value in the market. It might be easily imitated, requiring business model innovation as a means of creating value and maintaining a competitive advantage (Teece, 2010; 2018). Brandenburger and Stuart (1996) introduced 'appropriated value' as a suggested expansion of the concept of 'value creation.' 'Created value' presupposes the cost of opportunity and customer disposition to pay for the goods or benefits, depending on the external conditions of the business environment. As to the 'appropriated' or 'captured value,' it presupposes the price and the cost, both of which depend on the company's performance in this business context. Therefore, the conditions of creating and capturing value depend on the characteristics of buyers, firms, and suppliers in different business environments.

Pitelis (2009) validates this perspective by considering the creation of value as the value added by the company. Captured value, then, is the value seized by the firm from the business ecosystem (consumer, competitor, and supplier). These two concepts of value creation and value capture have become increasingly inseparable (Demil et al., 2015), as value capture might propel the creation of a new value and vice-versa.

Accordingly, the literature has coupled the concepts of 'value' and 'business model' as the beginning of a search for sustainable competitive advantage (Casadesus-Masanell and Ricart, 2009). The business model brings together the value proposition and the technological conditions as well as those of market resources. As such, the business model identifies the segments, the value chain structure and the profit potential (Chesbrough and Rosenbloom, 2002). The opportunity for participation and the involvement of partners, suppliers, customers, and even other companies from the same sector in value creation are new steps emerging in the business model literature (Massa et al., 2017; Zott and Amit, 2013).

For Massa et al., (2017), the creation of value established by business models through ecosystems breaks away from traditional strategy theories. That happens because it is not limited to pursuing value in the built demand, but in the identification of value in the search for customers and other members of the business ecosystem.

\section{The Dynamic Capabilities and the Dynamic Business Model (DBM)}

The long-term competitive advantage is at stake within environments portrayed by competition, uncertainty, discontinuity, rapid changes, technological remodelings and variations in consumer behavior. These conditions require, from the companies, a strategy that can identify, utilize and develop opportunities through entrepreneurial actions (Hitt et al., 2002). Following this perspective of change in the business environment and the 
strategy, dynamic capacities emerge in the literature as a means for reaffirming entrepreneurial strategies (Teece, 2014). This theory is understood as the capacity of companies to integrate, construct, and reconfigure internal and external resources to sustain continuous leadership in business environments (Teece et al., 1997).

The dynamic capabilities theory foundations are the strategic entrepreneurship and the Austrian School of Economics. The latter prescribes resource allocation through markets (Teece, 2014), balancing innovative behavior and the management perspective on risk, flexibility, and investment.

Despite that, the described strategic functions converge with three functions endorsed by dynamic capabilities.

The first is the sensing and shaping new opportunities and threats while involving the cognitive and creative capabilities of individuals, cocreation and organizational research, and development processes.

The second is seizing opportunities through actions such as bottleneck management (amongst assets) in the value chain, sharing business knowledge within a system of networks, creating mechanisms of safeguarding intellectual property rights, as well as combining knowledge from within the company and among companies.

The third is being able to transform threats and opportunities, recombining and configuring organizational assets and structures through decentralization, leadership, co-specialisation, governance and knowledge management (Teece, 2007).

Exercising these capabilities generates a continuous flow of technological innovations and opportunities that match the most critical market needs and comply with the resource capacity of the company (Teece, 2007).

There is another theoretical perspective, supported by Eisenhardt and Martin (2000) and Zollo and Winter (2002), which addresses dynamic capabilities as a set of processes and routines that are learned. As a result, they allow for adaptation and development, which intervene in making strategic decisions as well as alliances. From this perspective, dynamic capabilities might become a source of competitive advantage.
However, other authors point out the second approach: they assume that dynamic capabilities produce advantages. Peteraf et al. (2013) propose the convergence of these two perspectives, while Teece (2014) suggests naming the management of internal resources as the common capacities associated with the dynamic strategic capabilities of business promotion and innovation (Teece, 2014).

Zahra et al. (2006) consider the generation of dynamic capacities does not guarantee organizational success. That follows because the relation between the dynamic capabilities and the stout capabilities, also known as ordinary or second-order capacities (Easterby-Smith et al., 2009; Sniukas, 2015), is entangled and interwoven. The dynamic capability might be affected by organizational performance, as it requires direction as well as the involvement of the whole organization, mechanisms, and processes that manage and guide the business model (Sniukas, 2015).

The literature defines three organizational processes that contribute to the construction of dynamic capabilities. The first is the coordination/integration of the routines in the selection and combination of resources in the face of continuous change in product and service development, to avoid resource conflicts, misalignment, and incoherence (Teece, 2007;2018). That is also known as process orchestration (Sniukas, 2015).

The second is learning, experimentation, and the knowledge acquired by the company, the sector and the customers (Easterby-Smith et al., 2009; Sniukas, 2015; Teece, 2014, 2007; Zahra et al., 2006; Zollo and Winter, 2002).

The third is the reconfiguration or transformation of existing resources, requiring the creativity and swiftness of managers when adopting new processes (Teece, 2007), as well as mechanisms of implementation and reconfiguration of the business model which requires practices and methodologies able to generate alignment, result in analyses and routines (Sniukas, 2015). This converging position between managerial and strategic capabilities reinforces the fulfillment of the assumption of strategic entrepreneurship, which requires the integration within strategic and business actions (Hitt et al., 2002) while further promoting the balance between the Schumpeterian entrepreneurial behavior and the implementation and management actions. This topic has been addressed as an ambidextrous strategy that simultaneously combines the two 
actions (Altuntas, 2014; Demil et al., 2015; Hitt et al., 2002; Teece, 2014).

Similarly, as dynamic capabilities become linked to the business model, which has the function of rethinking, creating and adapting the business design, businesses respond to changes in the environment, to new technologies and new consumer preferences (Amit and Zott, 2015). The dynamism of the model lies in congregating a system of activities developed and activated to satisfy the needs of the markets (Zott and Amit, 2009). Besides, the model engages with the logic and provides data and other evidence on how firms create and deliver value to customers (Teece, 2010).

The integration of dynamic capabilities with the business model identifies a conceptual framework that combines and integrates the concepts of both dynamic and common capacities into the model. That should take place within the business ecosystem of the focal company to create value and generate a sustainable competitive advantage.

\section{A New Framework: The Dynamic Business Model}

This section will integrate the premises of dynamic capabilities and business model capacities in a business context. The goal is to build a DBM that will allow for the creation of value and sustainable advantage, thus leading to a theoretical framework that will be presented in Figure 1, shown below.

The dashed line in Figure 2 represents the business ecosystem, understood as the relation between the focal company and its customers, suppliers, shareholders, and competitors. The dashed line works as the background against which the constitution, management, improvement, and innovation within the business model takes place. This background provides dynamicity to the business model vis-à-vis the demands required by this business environment.

Accordingly, Teece $(2007 ; 2018)$ argues for the need of having dynamic business models that provide companies with the means to face new realities and foster their dynamic capacities.

The importance of the analysis of the environment within a business ecosystem is relevant because the behavior of companies tends to be idiosyncratic (Figure 2). This perspective impacts directly on the decision of the composition and proposition of business model value for each focal company, meaning that a given group might not be within the same business ecosystem.

In a stable or moderately variable business environment, the business model might sustain a competitive advantage for a more extended period. That is contrary to what happens in high uncertainty environments, which require the capacity of sensing opportunities and threats, making strategic decisions and changing directions when needed ( $\mathrm{Li}$ and $\mathrm{Liu}$, 2014).

On the right side of Figure 2, the indicator for dynamic competitiveness goes in two different directions, representing the levels of advantage acquired by the company. These advantages might be temporary, competitive and sustainable. On the left side of the same figure, the indicator also goes in two different directions, representing the gradual processes of value capture and value creation.

That notwithstanding, this framework proposes a relational reading of these indicators. That suggests that, as a result of value capture, the competitive dynamics established between companies might generate a temporary or sustainable competitive advantage. That means that value already existing in the market might be appropriated by the company through a business model, creating a competitive or temporary advantage. As the company appropriates this value, it is hard to imitate the advantage and the model for a period. It is possible to argue that there has been a progression of competitive advantage and, perhaps, a progression towards sustainable advantage.

According to this study, the creation of value and the generation of competitive advantage will only happen if there is a dynamism amongst the different strategic processes and resourcefulness in elaborating and implementing business (Demil et al., 2015). Figure 2 indicates that through a combined reading of the indicators on the left and right sides, which suggests the creation of value by a business model linked to the strategies of dynamic capabilities.

As previously mentioned, dynamic capabilities have the function of perceiving, molding and learning from actions, as well as transforming and innovating through opportunities and threats. Because of that, companies adopt mechanisms that will contribute to the effective fruition of dynamic capacities, which can be related to research, cocreation, organizational experiences and information applied to strategical analyses. 
As shown in Figure 2, dynamic capabilities interact with the standard capabilities of leadership, learning, and management of company process and routines. This convergence between strategic and management capabilities contribute to an attitude of improvement and innovation towards the business model, as managers effectively apply their knowledge, their entrepreneurial spirit and resource management (Penrose, 1989).

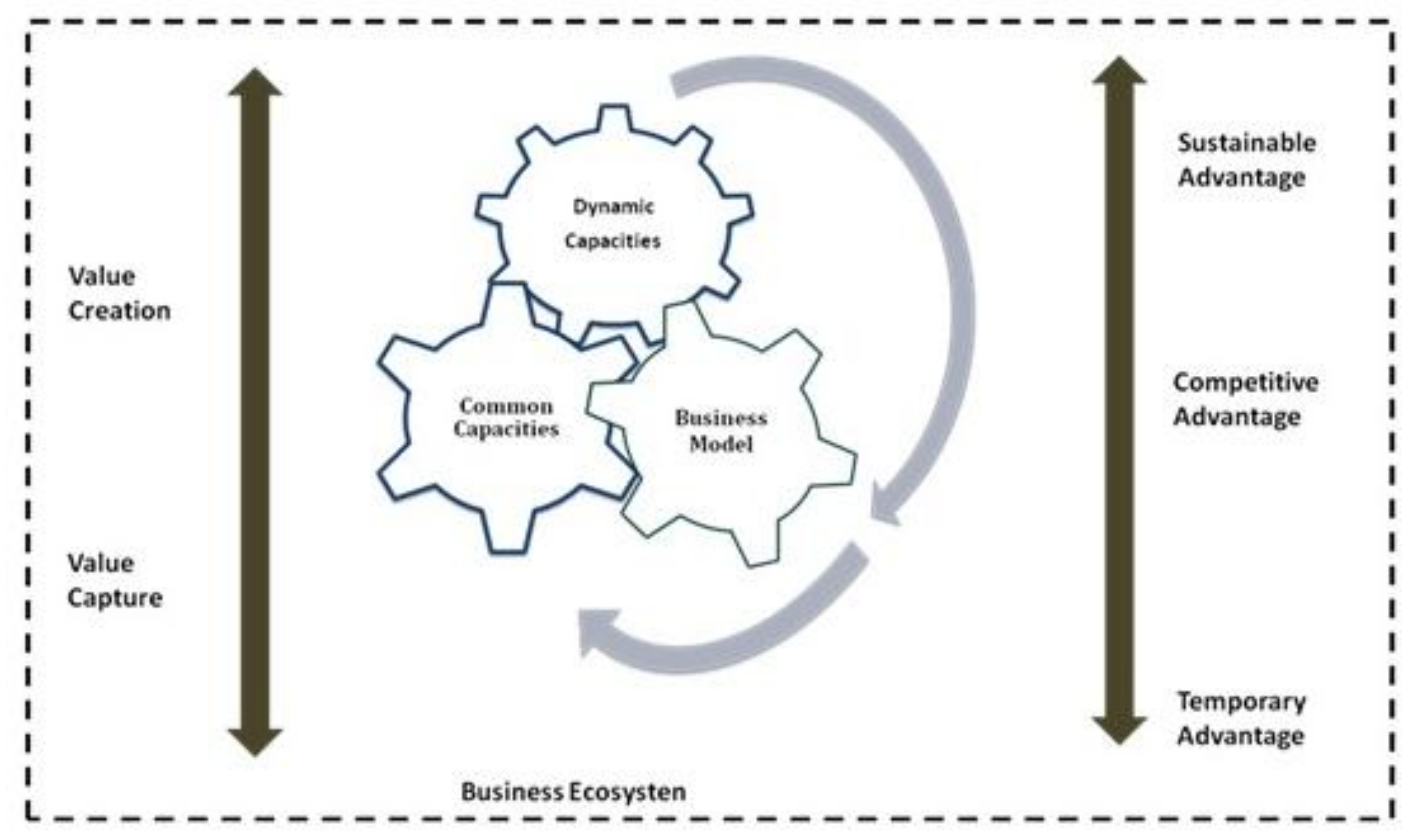

Figure 2: Value creation and sustainable advantage through a dynamic business model Source: Own elaboration.

Insofar as the business model holds the dynamic conditions of element interdependence and interconnection aligned with the strategic functions of dynamic capabilities supported by internal management capabilities, it must translate customer needs into a way of doing business (Plé et al., 2010b).

It must also adopt the design of the model to the preferences of customers and new technologies (Amit and Zott, 2014), as well as assist with decision making, whether to align with and negotiate external factors or to define internal resources (CasadesusMasanell and Heilbron, 2015).

Beyond these strategic functions, the DBM also requires other conditions, mentioned above in this study, such as the connection and interdependence of constitutive elements, metrics and quantitative and qualitative monitoring parameters and commitment to value creation.

\section{DBM Under A Dynamic Perspective}

Model Design Analysis: Interdependence and Connection Of Dbm Constitutive Elements
The literature on business models has been described as fragmented due to its historical development and the varied perspectives of authors (Demil and Lecocq, 2010; Osterwalder, 2004; Wirtz et al., 2016; Zott and Amit, 2013). In a not much different reality, the BMC concept - initially proposed by Osterwalder (2004) - has also changed through the years. Despite its commitment to value creation, the emphasis of the BMC concept was initially the unity of the business (Osterwalder, 2004). Later on, the concept included the creation, capture, and delivery of value, while also reinforcing the visual representation of the constitutive components of the business on board (Osterwalder and Pigneur, 2010).

Finally, the BMC concept focused on an accessible and understandable business model where value proposal features as the central element (Osterwalder et al., 2014).

However, it is possible to say that, despite their commitment to value creation and capture, BMCrelated concepts seem to assume the static function of a descriptive tool or picture of the business idea and components. 
According to Fritscher and Pigneur, 2015, the BMC framework has presented developments over time as a result of the criticisms it received since its initial formulation. The authors argue that there have been improvements in the structure of the model since the creation of the Canvas board (2009), which has enabled the simplification of the complexities of the business, making it intuitive and simple.

Nevertheless, this meant removing the markers for the relations and interactions between the constitutive components of the model, producing a fixed form of composition and analysis.

The process of grouping, as well as the links, connections, and dynamics between the components or activities of a framework, is considered to be fundamental for the scope of value creation and capture (Afuah and Tucci, 2003; Amit and Zott, 2015)

Although the literature on the BMC asserts the importance of the interrelation and interdependence of constitutive components, there is no demonstration that the Canvas framework is adequate in these areas.

The presentation of the BMC visual board does not provide the user with a defined order between components and their parameters and indicators that could establish an interdependence between these components and, consequently, between the blocks as provided by the conceptual idealization of the model.

The user can navigate freely on the Canvas board, which means they can define the relations between the components without drawing a correspondence between the latter. As a result, there is a lack of interaction and a loss of model design.

That reinforces the perception of the BMC as a static board featuring aleatory decisions and not, contrastingly, to what is advanced in its conceptual proposition, a model that represents a business conception that can be unprovable, compared with others and recreated. For this reason, the BMC design does not fulfill a dynamic perspective'.

\section{Analysis of the Strategic Conception of the Dynamic Capacities Applied to the BMC}

Wirtz et al. (2016) classify Osterwalder (2004) as a technology-based perspective, having later migrated to an organizational orientation. This categorization deserves further discussion since the BMC provides an inherently hybrid view of both the market (outside), referred to by the author as the 'right side,' and the organization (inside), referred to as the 'left side.' This strategic duality of the model is evident in the introduction, by Osterwalder and Pigneur (2010) of the components, particles conceptual detail and the reference bases for these two strategic visions (fig.3).

\begin{tabular}{|c|c|c|c|}
\hline Interface & Components & Concepts & References \\
\hline \multirow{5}{*}{$\begin{array}{l}\mathbf{C} \\
\mathbf{U} \\
\mathbf{S} \\
\mathbf{T} \\
\mathbf{O} \\
\mathbf{M} \\
\mathbf{E} \\
\mathbf{R}\end{array}$} & $\begin{array}{l}\text { Customer } \\
\text { segments }\end{array}$ & $\begin{array}{l}\text { Refer to the type of customer sought by the } \\
\text { company. }\end{array}$ & $\begin{array}{l}\text { Kotler; 1999; Hagel \& } \\
\text { Armstrong; 1977; Neal \& } \\
\text { Wurst; 2001. }\end{array}$ \\
\hline & $\begin{array}{l}\text { Value } \\
\text { proposition }\end{array}$ & $\begin{array}{l}\text { Refers to the bundle of products and services that } \\
\text { create value for a given customer segment. } \\
\text { Osterwalder e Pigneur ( } 2009 \text { ) describes it as } \\
\text { what motivates a customer to choose a given } \\
\text { company. }\end{array}$ & Kambil \& Ginsberg; 1997 \\
\hline & Channels & $\begin{array}{l}\text { Refer to how a company delivers the value } \\
\text { proposition to customer segments. Usually, a } \\
\text { company holds one or more direct and indirect } \\
\text { channels, separated by the links amongst them. }\end{array}$ & $\begin{array}{l}\text { Moriarty \& Moran; 1990; } \\
\text { Dolan; 2000; Ives \& } \\
\text { Learmonth 1984; Ives 1999; } \\
\text { Muther } 2002\end{array}$ \\
\hline & $\begin{array}{l}\text { Customer } \\
\text { relationship }\end{array}$ & $\begin{array}{l}\text { Refers to the relation between the company and } \\
\text { customer segments. }\end{array}$ & Blattberg \& Getz; 2001 \\
\hline & Revenue sources & $\begin{array}{l}\text { Refer to the periodic revenue about the value } \\
\text { offered by the company. They also define which } \\
\text { mechanism will be used to determine the price of } \\
\text { the offered value. }\end{array}$ & $\begin{array}{l}\text { Klein \& Loebbecke; 2000; } \\
\text { Pitt \& Berthon;1999 }\end{array}$ \\
\hline
\end{tabular}


Business Models and Competitive Advantage: A Dynamic Approach

\begin{tabular}{|c|c|c|c|}
\hline \multirow{4}{*}{$\begin{array}{l}\mathbf{C} \\
\mathbf{O} \\
\mathbf{M} \\
\mathbf{P} \\
\mathbf{A} \\
\mathbf{A} \\
\mathbf{N} \\
\mathbf{Y}\end{array}$} & Key activity & $\begin{array}{l}\text { Refers to the actions undertaken by a company to } \\
\text { do business and to meet the goals that it has set } \\
\text { for itself. }\end{array}$ & $\begin{array}{c}\text { Porter; } \\
\text { Fjeldstad \& Haanaes; } 2001\end{array}$ \\
\hline & Main resources & $\begin{array}{l}\text { Refer to the resources absorbed by the process of } \\
\text { value creation. } \\
\text { They describe the types of skill that the company } \\
\text { must have to provide value propositions. }\end{array}$ & Grant; 1991; Wernefelt; 1984 \\
\hline & $\begin{array}{l}\text { Main } \\
\text { partnerships }\end{array}$ & $\begin{array}{l}\text { Refer to the cooperation agreements between two } \\
\text { or more independent companies. They aim at } \\
\text { creating a project or conjoined activities through } \\
\text { the organization of the required capacities, } \\
\text { resources and activities. }\end{array}$ & $\begin{array}{l}\text { Child \& Faulkner, 1998; } \\
\text { Dussauge \& Garrette, 1999; } \\
\text { Brandenburger \& Nalebuff, } \\
1996 \text {; Tapscott \& Ticoll, } \\
2000 .\end{array}$ \\
\hline & Cost structure & $\begin{array}{l}\text { Refers to the measures all the monetary costs of } \\
\text { a company. }\end{array}$ & Maîte \& Aladjidi, 1999 \\
\hline
\end{tabular}

Figure 3- the Conceptual structure of the Business Model Canvas, 2009

Source: Own elaboration.

It is evident, however, that the BMC does not provide a defined strategic decision that could direct its activities as sustained by the DBM literature. It also lacks the mechanisms to manage and transform the model over time. From this perspective, the BMC inherently carries the conditions that could link it to a strategy of dynamic capabilities. That would allow for the continuous updating of the model, thus rendering it dynamic.

Nevertheless, this would require the creation of market and organizational routines and parameters (Amit and Zott, 2014) that could break with the current static and representative structure of the business model.

Another critical appraisal of the BMC version (2009) refers to the interface between the external environment and the model, which compromises the collection of information and its transformation into strategic action. The authors have made an effort to provide additional elements from the academic literature to assess environments and analyze scenarios combined with or adapted to the BMC.

Amongst the examples provided are the five forces model, SWOT analysis, Blue Ocean model of investment evaluation, and matrix management for multiple business models. Nevertheless, it is evident that there are a certain distance and lack of knowledge regarding these additional mechanisms when the model is applied.

In 2012, the new framework incorporated the proposition of value to the $\mathrm{BMC}$, introducing methodologies for the analysis of customer profile and value creation rooted in the needs of the customers. That notwithstanding, the model has yet to find an answer to the strategic approach to decision making, to be considered as a supporting tool for the analysis and reconfiguration of existing models.

\section{Analysis of the BMC as an Inducer of the Creation of Value and Generation of Sustainable Advantage}

The conceptualization of the established value proposition differentials is a component that describes the bundle of products and services that create value for a customer segment (Osterwalder, 2004; Osterwalder and Pigneur, 2010). The construction of the value proposition makes use of both the resource-based view - when it identifies the conditions for management and the infrastructure of the activity - and the positioning view - when it interprets the interface conditions between the company and consumers, distribution channels, and the relationship and communication with customers.

Such movement is a generating factor for the $\mathrm{BMC}$ revenue model and cost structure. However, the lack of fluidity in the construction and management of the business model might compromise its value proposition. Management relies on the interdependence between the components of the model, which creates dynamic integrated systems of actions that promote the value proposition.

That means the model can continuously be altered and improved. As to the construction of the model, it requires mechanisms for gathering and transforming external information associated with it.

Following the approach that addresses the business model as a competitive advantage, the definitions of the metrics for measuring value along 
business frameworks deserve further consideration. BMC's value equation considers revenue minus costs (Osterwalder and Pigneur, 2010). That is simplistic, as it does not allow for analysis of economic leverage that could justify delivering value on a larger scale. Furthermore, the lack of quantitative indicators amongst the model components might impair the generation of costs and incomes of a new BM.

According to Demil et al. (2015), research on the business model has surged in the past decades. However, there are rare cases of empirical research on the topic. It is then required to expand the understanding of the applied model and how it changes over time. As with other models, empirical research on the BMC has been scarce and thus does not allow for further testing of its theoretical assumptions.

Osterwalder has run a test on the empirical application of the business model for his 2004 thesis in which he analyses the case of the Montreux Jazz Festival. This analysis illustrates the difficulties in applying the model. The reason for this is the lack of quantitative and qualitative indicators that, when cross-checked, could provide an answer to the final equation of value generation as the author himself established in his theoretical framework.

$\mathrm{He}$ has also used additional techniques for measuring processes and resources, revealing that he applied instruments as well as details and definitions of indicators that are not present in the BMC theoretical proposal. That has impacted on the study carried out by financial institutions by Teixeira and Lopes (2016), who have assessed the creation of economic value from the BMC perspective.

\section{Conclusion}

This paper addresses how the DBM deals with value creation and the generation of sustainable advantage in unstable environments. The literature indicates that high-change, technological, complex and competitive environments impact on the competitive advantage.

As a result, they require dynamic mechanisms for constructing sustainable advantage and creating value. The business model could be one such mechanism.

The theoretical support for the conceptual framework proposed by the present study is rooted in existing studies on the relationship between dynamic capabilities and strategic entrepreneurship, aiming at the generation of sustainable advantage. To provide an answer to the research problem, it was, above all, required to establish connections and correlations between the constructs of dynamic competitive advantage and dynamic capabilities as well as to strengthen their relations with DBM theories.

This study shows that the business models are static when is set as a tool that merely describes the business logic of companies. However, to become dynamic and conducive to the creation of value and of sustainable competitive advantage, the model must create, implement and recreate businesses associated with a strategic perspective (CasadesusMasanell and Ricart, 2010; Pitelis, 2009).

Finally, the model design must guarantee the fluidity between the constitutive elements and promote interrelation and interdependence between them. It must also be able to be converted into parameters and metrics for management, evaluation, and alteration.

The conceptual framework of the BMC serves as a tool that describes the business logic of firms and how it connects to the strategy. That has, however, weak theoretical underpinning as there are no related mechanisms for gathering and transforming information that is external to the business. As a result, it does not incorporate the elaboration of the model into a strategic approach. The definition of the constitutive elements of the BMC finds support in various authors, but this interpretation offers an evasive description with no parameters for mensuration.

Furthermore, the route for defining the elements and the relationship between components has proven to be static given that there is no interaction, correspondence or interdependence between the components and blocks. Moreover, it is not clear how to manage the model, as it does not provide a record of the parameters used.

There is also no proposition of recursiveness or evaluation of the model. Given the actual BMC analyses, further empirical studies on the need for developing connectors between the elements must be pursued, relating them to quantitative and qualitative indicators that respond to the final equation of value. 
Business Models and Competitive Advantage: A Dynamic Approach

\section{References}

Achtenhagen, L., Melin, L., Naldi, L., 2013. Dynamics of Business Models - Strategizing, Critical Capabilities and Activities for Sustained Value Creation. Long Range Planning 46, 427-442. doi:10.1016/J.LRP.2013.04.002

Adner, R., Zemsky, P., 2006. A demand-based perspective on sustainable competitive advantage. Strategic Management Journal. doi:10.1002/smj.513

Afuah, A., Tucci, C.L., 2003. A model of the internet as creative destroyer. IEEE Transactions on Engineering Management 50, 395-402. doi:10.1109/TEM.2003.819651

Altuntas, G., 2014. The relationship between entrepreneurship and strategic management: a new model and test of strategic entrepreneurship. Journal of Business and Management 1, 103-129.

Amit, R., Zott, C., 2015. Crafting Business Architecture: the Antecedents of Business Model Design. Strategic Entrepreneurship Journal 9, 331350. doi:10.1002/sej.1200

Amit, R., Zott, C., 2014. Business Model Design: A Dynamic Capability Perspective. (Working). doi:10.1007/s13398-014-0173-7.2

Amit, R., Zott, C., 2001. Value Creation in EBusiness. Strategic Management Journal 22, 493520. doi:10.1002/smj.187

Barney, J.B., 1991. Firm Resources and Sustained Competitive Advantage. Journal of Management. doi:10.1177/014920639101700108

Brandenburger, A.M., Stuart, H.W.J., 1996. Value-Based Business Strategy. Journal of Economics \& Management Strategy. doi:10.1111/j.1430-9134.1996.00005.x

Casadesus-Masanell, R., Heilbron, J., 2015. The Business Model: Nature and Benefits. Pp. 3-30. doi:10.1108/S0742-332220150000033002

Casadesus-Masanell, R., Ricart, J.E., 2011. How to design a winning business model. Harvard Business Review 89. doi: Article

Casadesus-Masanell, R., Ricart, J.E., 2010. From strategy to business models and onto tactics. Long Range Planning 43, 195-215. doi:10.1016/j.lrp.2010.01.004

Casadesus-Masanell, R., Ricart, J.E., 2009. Strategy vs. business models vs. tactics. IESE Research Papers.

Chesbrough, H., Rosenbloom, R.S., 2002. The role of the business model in capturing value from innovation: evidence from Xerox Corporation' $\mathrm{s}$ technology spin-off companies. Industrial and Corporate Change 11, 529-555. doi:10.1093/icc/11.3.529

D’Aveni, R.A., Dagnino, G.B., Smith, K.G., 2010. The age of temporary advantage. Strategic Management Journal 31, 1371-1385. doi:10.1002/smj.897

DaSilva, C.M., Trkman, P., 2014. Business model: What it is and what it is not. Long Range Planning 47, 379-389. doi:10.1016/j.lrp.2013.08.004

Demil, B., Lecocq, X., 2010. Business model evolution: In search of dynamic consistency. Long Range Planning 43, 227-246. doi:10.1016/j.lrp.2010.02.004

Demil, B., Lecocq, X., Ricart, J.E., Zott, C., 2015. Introduction to the SEJ special issue on business models: Business models within the domain of strategic entrepreneurship. Strategic Entrepreneurship Journal 9, 1-11. doi:10.1002/sej.1194

Easterby-Smith, M., Lyles, M.A., Peteraf, M.A., 2009. Dynamic capabilities: Current debates and future directions. British Journal of Management 20. doi:10.1111/j.1467-8551.2008.00609.x

Eisenhardt, K.M., Martin, J.A., 2000. Dynamic Capabilities: What Are They? Strategic Management Journal Strat. Mgmt. J 21, 1105-1121. doi:10.1002/1097-

0266(200010/11)21:10/11<1105::AID-

SMJ133>3.0.CO;2-E

Fritscher, B., Pigneur, Y., 2015. Extending the Business Model Canvas: A Dynamic Perspective. Proc. International Symposium on Business Modeling and Software Design 5, 86-96.

Ghemawat, P., 2002. Competition and Business Strategy in Historical Perspective. Business History 
Review 76, 37-74. doi:10.2307/4127751

Gordijn, J., Akkermans, H., Vliet, H. Van, 2000. Business Modelling is not Process Modelling. Design 1921, 40-51. doi:10.1007/3-540-45394-6_5

Hitt, M.A., Ireland, R.D., Camp, S.M., Sexton, D.L., 2002. Strategic Entrepreneurship, Strategic Entrepreneurship.

doi:10.1111/b.9780631234104.2002.00012.x

Li, D. Yuan, Liu, J., 2014. Dynamic capabilities, environmental dynamism, and competitive advantage: Evidence from China. Journal of Business Research 67, 2793-2799. doi:10.1016/j.jbusres.2012.08.007

Magretta, J., 2002. Why business models matter. Harvard Business Review. doi:10.1002/10990690(200112)2001:23<4391::AIDEJOC4391>3.0.CO;2-D

Massa, L., Tucci, C., Afuah, A., 2017. A Critical Assessment of Business Model Research. Academy of Management Annals 11, 73-104. doi:10.5465/annals.2014.0072

Nelson, R.R., Winter, S.G., 1982. An evolutionary theory of economic change, Cambridge MA Belknap. doi:10.2307/2232409

Osterwalder, A., 2004. The Business Model Ontology - A Proposition in a Design Science Approach. Business Doctor, 1-169. doi:10.1111/j.1467-9310.2010.00605.x

Osterwalder, A., Pigneur, Y., 2010. Business Model Generation: A Handbook for Visionaries, Game Changers, and Challengers, A handbook for visionaries, game changers, and challengers. doi:10.1523/JNEUROSCI.0307-10.2010

Osterwalder, A., Pigneur, Y., 2002. An ebusiness model ontology for modeling e-business. 15th Bled Electronic Commerce Conference, June 17-19 12. doi:10.1.1.16.633

Osterwalder, A., Pigneur, Y., Bernarda, G., Smith, A., 2014. Value proposition design, Strategyzer doi:10.1017/CBO9781107415324.004

Osterwalder, A., Pigneur, Y., Tucci, C.L., 2005. Clarifying business models: origins, present, and future of the concept. Communications of the Association for Information Systems 15, 1-43. doi:10.1.1.83.7452

Penrose, A.M., 1989. Strategic differences in composing: Consequences for learning through writing.

Peteraf, M., Di Stefano, G., Verona, G., 2013. The elephant in the room of dynamic capabilities: Bringing two diverging conversations together. Strategic Management Journal 34, 1389-1410. doi:10.1002/smj.2078

Pitelis, C., 2009. Value Capture from Organizational Advantages and Sustainable Value Creation. Papers.

Plé, L., Lecocq, X., Angot, J., 2010a. Loïc PLÉ Xavier LECOCQ Jacques ANGOT. Program 13, 226-265. doi:10.3917/mana.134.0226

Plé, L., Lecocq, X., Angot, J., 2010b. Customerintegrated business models: A theoretical framework. Management 13, 226-265. doi:10.3917/mana.134.0226

Porter, M.E., Millar, V.E., 1985. How information technology gives you competitive advantage. Harvard Business Review 12.

Priem, R.L., 2007. A Consumer Perspective on Value Creation. Academy of Management Review 32, 219-235. doi:10.5465/AMR.2007.23464055

Shafer, S.M., Smith, H.J., Linder, J.C., 2005. The power of business models. Business Horizons. doi:10.1016/j.bushor.2004.10.014

Sniukas, M., 2015. The micro-foundations of business model innovation as a dynamic capability 336.

Teece, D., Pisano, G., Shuen, A., 1997. Dynamic capabilities and strategic management. Strategic Management Journal 18, 509-533. doi:10.1002/(SICI)1097-

0266(199708)18:7<509::AID-SMJ882>3.0.CO;2-Z

Teece, D.J., 2010. Business models, business strategy and innovation. Long Range Planning 43, 172-194. doi:10.1016/j.lrp.2009.07.003

Teece, D.J., 2007. Explicating dynamic capabilities: The nature and microfoundations of (sustainable) enterprise performance. Strategic Management Journal 28, 1319-1350. doi:10.1002/smj.640 
Teece, D.J, 2014.The foundations of enterprise performance: dynamic and ordinary capabilities in(economic) theory of firms. The Academy of Management Perspectives, vol. 28, No. 4, 328-352. http://dx.doi.org/10.5465/amp.2013.0116

Teece, D.J, 2018. Business models and dynamic capabilities. Long Range Planning v.51, p. 40e49.

Teixeira, L. de C.M., Lopes, H.E.G., 2016. Application Model Canvas to the business model of the Bank of Brazil and Caixa Econômica Federal. Gestão E Tecnologia 16, 73-99. doi:http://dx.doi.org/10.20397/21776652/2016.v16i2.812

Wirtz, B.W., Pistoia, A., Ullrich, S., Göttel, V., 2016. Business Models: Origin, Development and Future Research Perspectives. Long Range Planning 49, 1-19. doi:10.1016/j.lrp.2015.04.001

Zahra, S.A., Sapienza, H.J., Davidsson, P., 2006. Entrepreneurship and dynamic capabilities: A review, model and research agenda. Journal of Management Studies 43, 917-955. doi:10.1111/j.1467-6486.2006.00616.x

Zollo, M., Winter, S.G., 2002. Deliberate Learning and the Evolution of Dynamic Capabilities $13,339-351$.
Zott, C., Amit, R., 2013. The business model: A theoretically anchored robust construct for strategic analysis. Strategic Organization 11, 403-411. doi:10.1177/1476127013510466

Zott, C., Amit, R., 2010. Business model design: An activity system perspective. Long Range Planning 43, 216-226. doi:10.1016/j.lrp.2009.07.004

Zott, C., Amit, R., 2007. Business Model Design and the Performance of Entrepreneurial Firms. Organization Science 18, 181-199. doi:10.1287/orsc. 1060.0232

Zott, C., Amit, R., Massa, L., 2010. The Business Model: Theoretical Roots, Recent Developments, and Future Research. Business 3, 1-45. doi: $10.1177 / 0149206311406265$

Zott, C., Amit, R.H., 2009. Designing Your Future Business Model: An Activity System Perspective. Long Range Planning 43, 216-226. doi:10.2139/ssrn.1356511 